\title{
The Role of a Bone SPECT/CT Scan in the Follow-up of a Solitary Bone Lesion in a Patient with Langerhans' Cell Histiocytosis
}

\author{
Langerhans Hücreli Histiyositoz Tanılı Hastada Soliter Kemik Lezyonunun Takibinde \\ Kemik Sintigrafi ve SPECT/BT'nin Rolü
}

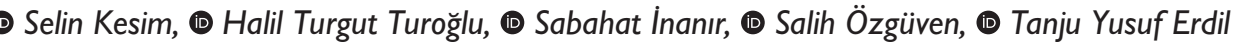

Marmara University Pendik Training and Research Hospital, Clinic of Nuclear Medicine, Istanbul, Turkey

\begin{abstract}
Langerhans' cell histiocytosis (LCH) is a rare disease observed in childhood characterized by the proliferation of Langerhans' cells resulting in focal or systemic manifestations (including the bones). Here, we present a pediatric case with a localized biopsy-proven LCH, who underwent progression from solitary to multifocal form detected on bone scintigraphy and single photon emission computerized tomography/computed tomography (SPECT/CT) performed within four months. Emphasizing on localized bone pain (predictive of osseous LCH) and local tenderness and swelling usually guides the nuclear physician to perform additional SPECT/CT with presumably an improvement of the diagnostic accuracy as demonstrated in our case.

Keywords: Langerhans' cell histiocytosis, technetium-99m-methylene diphosphonate bone scintigraphy, bone SPECT/CT
\end{abstract}

\section{Öz}

Langerhans hücreli histiyositoz (LHH), genellikle çocukluk çağında görülen, Langerhans hücrelerinin çoğalmasıyla birlikte kemikler de dahil olmak üzere lokal veya sistemik tutulum ile seyreden nadir bir hastalıktır. Burada, soliter olup dört ay sonra yapılan kemik sintigrafisi ve tek foton emisyon tomografisi/bilgisayarlı tomografide (SPECT/BT) multifokal forma ilerlediği saptanan, biyopsi ile kanıtlanmış LHH tanılı pediatrik bir olgu sunulmaktadır. Bu olguda görülmektedir ki; lokalize kemik ağrısı şikayeti olan ve/veya fizik muayenede lokal hassasiyet ve şişme gibi bulguları olan hastalarda, ilgili alanın ek SPECT/BT görüntülerinin alınması ile tanısal doğrulukta iyileşme sağlamaktadır.

Anahtar Kelimeler: Langerhans hücreli histiyositoz, teknesyum-99m-metilen difosfonat kemik sintigrafisi, kemik SPECT/BT

Address for Correspondence: Selin Kesim MD, Marmara University Pendik Training and Research Hospital, Clinic of Nuclear Medicine, İstanbul, Turkey Phone: +90 2163968648 E-mail: selinkesim@yandex.com ORCID ID: orcid.org/0000-0002-6164-9781 Received: 28.04.2020 Accepted: 29.06.2020

${ }^{\circ}$ Copyright 2021 by Turkish Society of Nuclear Medicine Molecular Imaging and Radionuclide Therapy published by Galenos Yayınevi. 
A

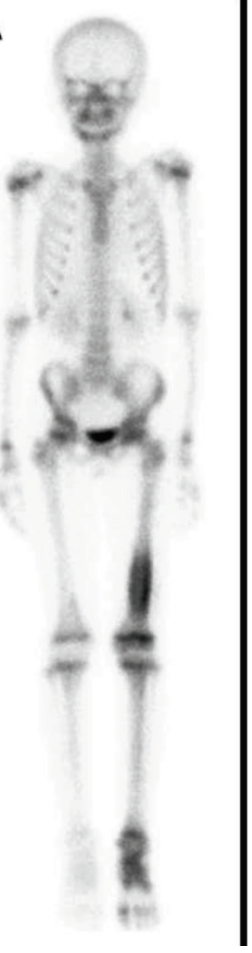

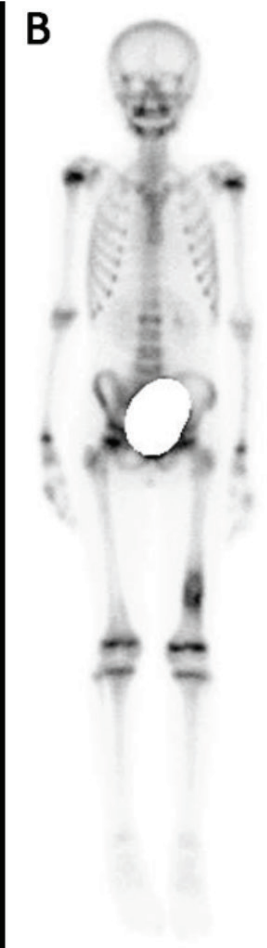

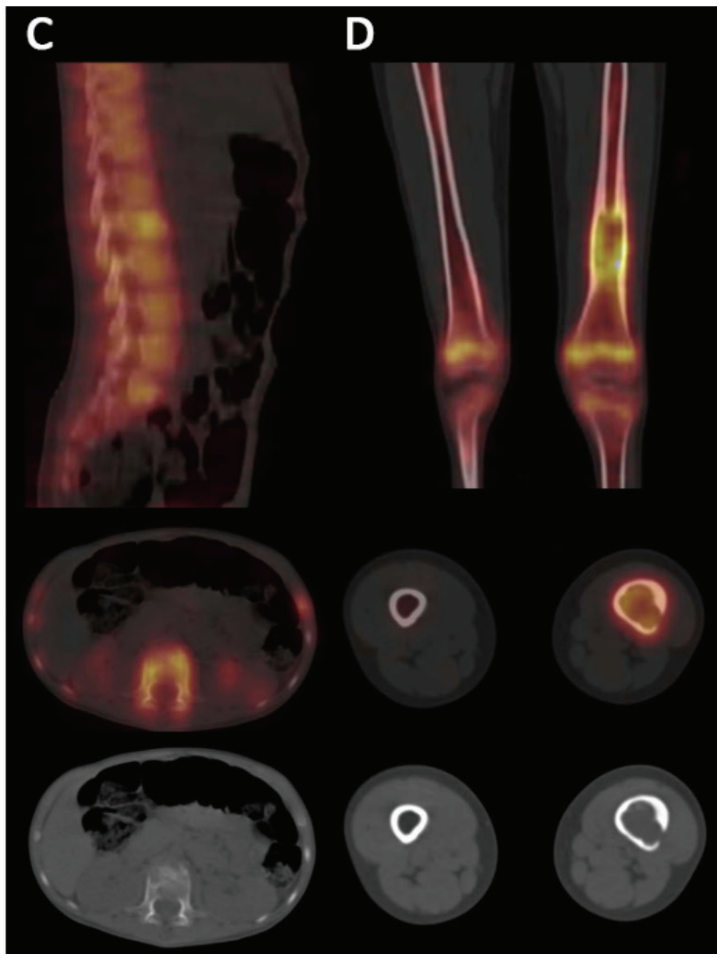

Figure 1. (A) An 11-year-old girl presented with left-leg pain and limping without history of trauma; was referred for technetium-99m-methylene diphosphonate whole-body bone scintigraphy (BS). Baseline BS revealed a marked radiotracer uptake only in the distal part of the left femoral diaphysis. In addition, an increased Tc-99m MDP uptake was observed in the left tibiotalar and tarsal region.

(B) The tru-cut biopsy demonstrated mononuclear cells with S-100 and CD1a immunoreactivity. This was consistent with Langerhans' cell histiocytosis $(\mathrm{LCH})$, and the patient underwent two cycles of chemotherapy. Four months later, the patient started complaining of low back pain and was referred to do a control BS, which showed a slightly increased radiotracer uptake in the L2 vertebra.

(C) Single photon emission computerized tomography/computed tomography (SPECT/CT) images showed a new L2 lytic lesion.

(D) The initial left femoral lesion also persisted with well-defined lytic lesion, having an expanded appearance with endosteal scalloping and accompanying cortical destruction.

LCH refers to a group of diseases associated with the accumulation of Langerhans' cells, resulting in focal or systemic manifestations (involving the bone, lung, skin, central nervous system, liver, spleen, thymus, lymph nodes, and bone marrow). LCH previously known as eosinophilic granuloma (the localized form of LCH), histiocytosis X, Langerhans' cell granulomatosis, mostly occurs in childhood. Syndromes such as Hand-Schuller-Christian disease (classic triad of skull lesions, exophthalmos, and diabetes insipidus) and the Letterer-Siwe disease (disseminated lesions involving multiple visceral organs) are also included in this spectrum (1). About 50\% of patients with LCH have osseous lesions only involving the cranium, legs, vertebral column, and pelvis. Early lesions tend to have an aggressive appearance, with poorly defined margins, while mature lesions depict sclerotic borders and expanded appearance. In the vertebral column, early osseous LCH lesions appear lytic, followed by a uniform collapse which result in the "coin on edge" or vertebra plana in cases of extreme vertebral collapse. The posterior elements of the vertebrae are rarely involved, thereby differentiating LCH from osseous metastases. When a single bone is involved, the disease is usually self-limited; but multiple bone involvement progresses to a systemic disease and has a less favorable prognosis (2). BS has been considered as the most sensitive test for the detection of clinically active osseous lesions of LCH. However, in patients with localized acute bone pain and/or inflammatory signs (local tenderness and swelling), an additional SPECT/CT of the involved area should be performed to enable early detection of the disease. Moreover, some studies in the literature reveal that ${ }^{18}$ fluorine-fluorodeoxyglucose $\left({ }^{18} \mathrm{~F}-\mathrm{FDG}\right)$ positron emission tomography/computed tomography (PET/CT) has a higher sensitivity in detecting metabolically active lesions not detected on conventional imaging; with the advantages of providing an anatomical evaluation and identifying occult multi-organ involvements $(3,4)$. The initial presentation of our case was an isolated bony lesion of $\mathrm{LCH}$; which is associated with a good prognosis with spontaneous regression. However, followup BS revealed a second osseous lesion. Therefore, categorizing the case in the initial and follow-up imaging using bone scan and/or ${ }^{18} \mathrm{~F}-\mathrm{FDG}$ PET/CT for the prognosis and treatment of LCH is of utmost importance $(5,6,7,8)$. Hybrid imaging combining SPECT with a low-dose CT has proven to improve diagnostic accuracy and to guide clinicians on decision making as demonstrated in our case. 


\section{Ethics}

Informed Consent: All appropriate patient consent forms were obtained. In the form, the patient gave consent for their pictures and other clinical information to be reported in the journal.

Peer-review: Externally and internally peer-reviewed.

\section{Authorship Contributions}

Surgical and Medical Practices: S.K., H.T.T, S.I., S.Ö., T.Y.E., Concept: S.K., H.T.T., Design: S.K., H.T.T. Data Collection or Processing: S.K., H.T.T., Analysis or Interpretation: S.K., H.T.T., Literature Search: S.K., H.T.T., Writing: S.K., H.T.T.

Conflict of Interest: No conflict of interest was declared by the authors.

Financial Disclosure: The authors declared that this study received no financial support.

\section{References}

1. Azouz EM, Saigal G, Rodriguez MM, Podda A. Langerhans' cell histiocytosis: pathology, imaging and treatment of skeletal involvement. Pediatr Radiol 2005;35:103-115.
2. Stull MA, Kransdorf MJ, Devaney KO. Langerhans cell histiocytosis of bone. Radiographics 1992;12:801-823.

3. Lee HJ, Ahn BC, Lee SW, Lee J. The usefulness of F-18 fluorodeoxyglucose positron emission tomography/computed tomography in patients with Langerhans cell histiocytosis. Ann Nucl Med 2012;26:730-737.

4. Koç ZP, Şimşek S, Akarsu S, Balcı TA, Onur MR, Kepenek F. Insufficiency of bone scintigraphy in vertebral lesions of langerhans cell histiocytosis compared to f-18 fluorodeoxyglucose positron emission tomography/ computed tomography and diagnostic computed tomography. Mol Imaging Radionucl Ther 2015;24:21-24.

5. Agarwal KK, Seth R, Behra A, Jana M, Kumar R. 18F-Fluorodeoxyglucose PET/CT in Langerhans cell histiocytosis: spectrum of manifestations. Jpn J Radiol 2016;34:267-276.

6. Sasaki H, Nagano S, Shimada H, Nakamura S, Setoguchi T, Komiya S. Clinical course of the bony lesion of single-system single-site Langerhans cell histiocytosis - Is appropriate follow-up sufficient treatment? J Orthop Sci 2018;23:168-173.

7. Howarth DM, Mullan BP, Wiseman GA, Wenger DE, Forstrom LA, Dunn WL. Bone scintigraphy evaluated in diagnosing and staging Langerhans' cell histiocytosis and related disorders. J Nucl Med 1996;37:1456-1460.

8. Dogan AS, Conway JJ, Miller JH, Grier D, Bhattathiry MM, Mitchell CS. Detection of bone lesions in Langerhans cell histiocytosis: complementary roles of scintigraphy and conventional radiography. J Pediatr Hematol Oncol 1996;18:51-58. 